\title{
Hereditary disorders of blood coagulation factors amongst
}

Jews!

\section{Hilary Denis Solomons}

P.O.Box 64203, Highlands North, South Africa.

*Corresponding author: Hilary Denis Solomons, P.O.Box 64203, Highlands North, South Africa.

Received date: July 23, 2020; Accepted date: July 29, 2020; published date: August 04, 2020

Citation: Hilary Denis Solomons. Hereditary disorders of blood coagulation factors amongst Jews!. J Clinical Research and Reports, 5(1); DOI:10.31579/2690-1919/113

Copyright: (c) 2020 Hilary Denis Solomons. This is an open access article distributed under the Creative Commons Attribution License, which permits unrestricted use, distribution, and reproduction in any medium, provided the original work is properly cited.

Factor XI (plasma thromboplastin antecedent) deficiency is frequently found amongst Ashkenazi Jews.

This is picked up on routine bloods such as partial thromboplastin times. The prothrombin time is usually normal. There is no excess bleeding after trauma. They may however still bleed excessively after surgery.

In terms of treatment or therapy the factor XI level must be kept at greater than $30 \%$ with fresh frozen plasma 5-20 ml./kg./ day. The inheritance is autosomal recessive.In Israel the incidence is 8\% amongst Ashkenazi Jews.

FactorXI deficiency is also known as; Rosenthal Syndrome or Haemophilia C.

Sometimes the child may bleed excessively e.g. at circumcision but they do not bleed as severely as haemophiliacs (factor VIII deficiency) and rarely present with haemarthroses. Haemorrhage is usually from mucousal surfaces.

Factor XI concentrate is available but is difficult to obtain. The amount of factor XI in fresh frozen plasma is minimal and for this reason large volumes have to be given.

Ashkenazi Jews are usually of European descent and Sephardi jews are usually of Spanish descent. But non- Jews may present with the disorder, largely due to assimilation.

There are two predominant mutations, type II and III (using an older classification system). The type III mutation is an amino acid substitution (Phe283Leu) resulting in a missense mutation. This results in impaired dimerization and secretion of the factor XI molecule. The second is the type II mutation; this causes premature chain termination and results in very low levels of circulating factor XI.

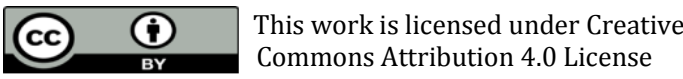

To Submit Your Article Click Here: Submit Article

DOI: $10.31579 / 2690-1919 / 0113$
Ready to submit your research? Choose Auctores and benefit from:

$$
\begin{aligned}
& \text { fast, convenient online submission } \\
& \text { rigorous peer review by experienced research in your field } \\
& \text { rapid publication on acceptance } \\
& \text { authors retain copyrights } \\
& \text { unique DOI for all articles } \\
& \text { immediate, unrestricted online access }
\end{aligned}
$$

At Auctores, research is always in progress.

Learn more www.auctoresonline.org/journals/journal-of-clinicalresearch-and-reports 